\title{
Recruitment, Certification And Financial Management Of Political Party In The Province of North Sumatera, Indonesia
}

\section{Muryanto Amin, Warjio, Heri Kusmanto}

Department of Political, Faculty of Social and Political Sciences University of Sumatera Utara Medan, Jl. Dr. Sofyan No.1 Medan, 20155, Telepon: 061-8220760

\begin{abstract}
The management of political parties in relatively new countries implement procedural democracy is done transactionally. Not following documented recruitment and regeneration models and weak transparency of financial management of political parties. As a result government management becomes inefficient, tend to corrupt, and poor public services. The purpose of this study is to explain the relation between the management of undemocratic political parties and good governance. Taking the case in North Sumatra, one of the provinces in Indonesia, which has a high level of corruption.The research method chosen is qualitative through FocusGroupDiscussion (FGD) and indepth interview with political party elite, academic, government element and representative of observer society of political party in North Sumatera. The results showed that recruitment by political parties to become political officials was done transactionally. The majority of political parties do not have structured and systematic regulatory documents, as well as financial management that are largely not from party contributions, but non-binding contributions from cadres who have become political officials. Funding for the activities of political parties is highly dependent on political party contributions derived from government budgets outside the rules. This has resulted in weak governance in North Sumatra, as evidenced by high levels of corruption and relatively slow pace of development.
\end{abstract}

Keywords: political parties, political recruitment, management of political parties, good governance

\section{PREFACE}

Post-Reformation democratization has changed the face of politics in Indonesia, both at national and local level (Choi, 2011).The transformation of post-New Order political parties seeks to exclude undemocratic practices, although some still leave the military and elite elements of the New Order oligarchy (Fukuoka, 2013). Furthermore, the dynamics of model relations and the form of political party activities with democratic principles are increasingly a concern in Indonesia.

The analysis between the normative function of political parties and those carried out empirically is one of the more widespread studies today (Bader, 2014). The study of political parties in a democratic state is well founded, because political parties are the main channel that liaises between communities through their representatives in parliament with the state, and acts to control the course of power (Dahl, 1971).Political parties are the main key in implementing democratic consolidation so that the principle of representation can be done (Kalua, 2011). While there is broad agreement that political parties play an important role in the consolidation of democracy, there is little agreement about what particular qualities the parties should have (Randall \&Svåsand, 2002).

Democracy implementation indicators, as mentioned above, do not occur very well in political parties. The activities of political parties are always seen in the context of political inconsistencies. One of the issues that need attention is the relationship between political parties and the development of democracy. Indirect democracy applied in almost all modern countries, including Indonesia, makes political parties the main and most important pillar for the implementation of representative democracy.The people can not rule directly as in Athens in the 5th century BC. To enable the implementation of the government, the people should entrust their political rights to their representatives in the legislature (DPR), while these representatives are recruited through the existing political parties and eligible to be elected.

At the local level in Indonesia, the current conditions are in line with the increasingly democratic national dynamics. The direct election of regional heads, for example, mirrors efforts to increase democracy at the local level.In this condition, the role of political parties is getting stronger as a guarantor of the implementation of 
the democratic process openly and accessible to all levels of society. The major challenge for political parties in Indonesia today is the management of recruitment and placement of cadres in political positions and party cadresisations that have not been properly implemented, and also the centralization of all activities and decisions of political parties in the central board.

Quoted by Robert Dahl, political parties constitute the most important part of the political life of society, as it balances the executive power through its representatives in parliament in controlling the course of power. If the balance can be carried out in accordance with the normative concept, it is certain that there will be democratic practice correctly. In the concept of such democracy, political parties have a strategic role in developing democratic political life. In Indonesia for example, currently to be president must be through the door of the party, others should not be. This means that political parties will have an effect on the process of democratic development, because in reality political parties have such great authority, especially in leadership recruitment (Dahl, 1971; Diamond, 1999).

This discrepancy should be the concern of political parties in terms of their role as the main pillars of indirect democracy. We are faced with the possibility of the emergence of unstable Indonesian democracy because the political parties that become his teacher's shirt do not show political stability in him. Freedom of choice can be guaranteed and well implemented in national politics, while freedom of choice in political parties is relatively restrained.Consequently, there is a strong tendency that there will be disruption of national political integration because political parties are always threatened with political disintegration. The condition may require that all constituents change the opinion that a de jure political party is a pillar of democracy, de facto absence of its contribution to Indonesian democracy. More sharply, political parties in Indonesia have no role to play in contributing to the substantive production of democracy in Indonesia. The political party still plays the main consumer of democracy produced by other social forces, such as the media, civil society groups, academics, labor and fishermen movements, women's movements and various pressure groups that have emerged in turn in political development.

In his study regarding the role of civil society towards democratization in Indonesia, Otho H. Hadi concludes that civil society groups now have sufficient capacity and are able to positively influence the management of state and civil society relations. The group then became a patron (indirectly) for the growth of new civil society groups, in which capacity in organizational management, fund management, and network capacity with institutions at national and international levels. With such influence, democratization in Indonesia is not separated from the significant role of civil society. The event of major political changes during the early days of the New Order and its end, it is difficult to find the role of political parties in encouraging change, compared to the role of other community groups such as university students. It is more appropriate to say that political parties are those who enjoy political change driven by other social forces. When we look closely at this, there are two more widespread trends in our political practice and also in the behavior of political parties.

First, busyness with self tends to be higher in intensity than the ability to open up to be confronted with outside experiences. This selfcentered attitude marks a high degree of maturity, just as a child sees itself as the center of the world so everything must be tailored to its desires. Both trivialism, the tendency to be preoccupied with minor less important things because of the lack of perspective to see and engage in a common cause (common cause) must be fought for. Mind and orientation on a big goal will relativize obstacles by the small things that are often connected with self-interest.

\section{RESEARCH METHODS}

This research uses qualitative approach with case study as research strategy. The choice of qualitative approach is done with the aim to describe and analyze the social phenomenon that 
is happening (Yin, 2009). Therefore, this type of research uses an explanatory case study strategy. This research was conducted in North Sumatera Province, which are political partieshavingseats in Regional Representatives Council Province of North Sumatera and members of Regional Representatives Council Province of North Sumatera. According to Lofland and Lofland, the main data sources in qualitative research are words and actions. The main data source is recorded through written notes or through video / audio recording, photo shooting or film (Lofland\&Lofland, 1995).

This research uses three techniques of data collection that is, first, documentation. Second, in-depth interview. Thirdly make observations to provide new dimensions so as to understand the context of one phenomenon under study such as photographs or during interaction between party leaders with their constituents and other groups, and other events relevant and relevant to the research topic. Fourth, to look for political education model between legislative candidate and youth organization group will be Focus Group Discussion (FGD) with key informant of political party leader, candidate member of The House of Representatives of the Republic of Indonesia, political scientist, education figure and nongovernmental organization.

Qualitative analysis technique with typology is done based on the author's interpretation of the data both written materials, interviews and observation. The impossible possibility that the author believes is that an actor is confident and honest about what he says. Therefore, to avoid or minimize the possibility of bias, the authors try to match the results of interviews between one resource person to another then from documents found on the activities of political parties

\section{LITERATURE REVIEW}

A.Preliminary Study.

Research conducted by Paul Webb, Monica Poletti and Tim Bale (2017) related to the role of cadres and non-cadres in campaigning for political parties in Britain (The Labor, Conservative, Liberal Democrats, United Kingdom
Independence, Scottish Nationalist, and Green parties) concluded that in aggregate, sympathizers of parties (non-cadres) work more in campaigning for political parties than the party cadres themselves. This shows that the process of internalizing the platform of political parties and regeneration is still not linear with the level of activeness of cadres in campaigning political parties (Webb, Poletti, \& Bale, 2017).

Further related to the political party delivered by Susan Scarrow. Susan argues that parties in democracies often adapt to the reality of a widely recognized membership reduction that seeks to involve citizens outside of their members with alternative affiliate options. In other words, there is a process in which the political party recruits instantly the people (characters) who are considered capable of vote voting to maintain the party's electoral existence (Scarrow, 2009).

Cross and Gauja in Australia identified the organizing of community groups outside the party cadres conducted by the Australian Labor Party (Cross \&Gauja, 2014). In Britain, under the leadership of Ed Milliband, the Labor Party also organizes groups outside the base of the party cadre secretly (Bale, 2015).

Although the idea of a political party is not only related to members or cadres, there are other affiliates, such as Duverger, for example, distinguishing elements within political parties, namely Voters, Supporters, Members (cadres) and Party Militants (DUVERGER, 1980) . But as one of the important functions of political parties, recruitment and cadreisation is certainly measured by the extent to which cadres are able to work more and are able to implement the party platform when the cadre sits in one political office compared to other elements of the party (supporters and voters).

Political parties have a very important position (status) and role (role) in every democratic system. The Party plays a very strategic liaison role between government processes and citizens. Even many argue that the political party that actually determines the democracy, "political parties created democracy". Political parties are a very important pillar for the strengthening of the institutionalization degree in 
every democratic political system "modern democracy is unthinkable save in terms of the parties" (Schattschneider, 1942).

However, there are also many critical and even skeptical views of political parties, among which state that the political party is actually nothing more than a political vehicle for a group of ruling elites or intends to satisfy its own 'lust of power'. Political parties serve only as a tool for the lucky few who succeed in winning the voice of the gullible people, to impose the enactment of certain public policies' at the expense of the general will or the common good (Rousseau 1999).

Every democratic country, the position and role of state institutions must be as strong and controlling in the "checks and balances" relationship. However, if the state institutions are not functioning properly, their performance is ineffective, or the weakness of the authority of the institution in carrying out their respective functions, then what often happens is a nondemocratic political party that will control and control the entire process of organizing functions government.

Therefore, a good party system will determine the functioning of the state administration system based on the principle of "checks and balances" in a broad sense. In contrast, the effective functioning of the state's institutional functions in accordance with the principles of checks and balances under the constitution also greatly determines the quality of party systems and the mechanisms of democracy developed in a country. All this is certainly closely related to the dynamics of growth of tradition and culture of free thinking in social life. The tradition of thought or freedom of thought in turn influences the growth and development of the principles of freedom of association and assembly in the dynamics of the life of democratic societies concerned.

Political parties are one of the institutional forms of society to realize the expression of ideas, thoughts, views, and beliefs in a democratic atmosphere. In addition to political parties, other forms of expression are also embodied in the form of freedom of the press, freedom of association, or freedom of association through non-political party organizations such as NGOs, and so forth.

However, in relation to the activities of the state, the role of political parties as media and means certainly stands out. In addition to other institutions such as free press and the role of an enlightened middle class, etc., the role of political parties can be said to be very decisive in the dynamics of state activities. Political play, however, also plays a role in the dynamic process of values and interests of the constituents it represents to determine policy in the context of state activities. Political parties that act as intermediaries in state decision-making processes, connecting citizens with state institutions. According to Robert Michels in his book, "Political Parties, A Sociological Study of the Oligarchical Tendencies of Modern Democracy", "... organizations are the only means of economy or politics to form collective will" (Michels 1962).

The process of institutionalizing democracy is ultimately largely determined by the institutionalization of political party organizations as an integral part of the democratic system itself as Yves explained, "A democratic system without political parties or with a single party is impossible or at any rate hard to imagine "(Mený\& E-mail, 2002). A political system with only one political party is hard to imagine to be called democratic, especially if it is without a political party at all.The degree or degree of institutionalization of the political party itself in the democratic system, according to Yves Meny, depends on 3 (three) parameters, namely (i) its age, (ii) the depersonalization of organization, and (iii) organizational differentiation "(Mený\& E-mail, 2002) Every normal organization grows and develops naturally according to its own timeline. The older age, the ideas and values adopted within the organization are increasingly institutionalized into a tradition within the organization.

Organizations that develop more institutionalized tend to also experience the process of "depersonalization". Insiders and outsiders alike are aware of and treat the organization concerned as an institution and not 
to be confused with the personal or personal issues of individuals who happen to be their caretakers. Many organizations, despite their very old age, have not built a tradition whose personal affairs of the administrators are completely separate and separated from organizational matters. This means that the institutional degree of the organization as an institution, still not strong, or more firmly has not been institutionalized as a strong organization. If this is related to the reality of Indonesia, there are many social organizations whose stewardship is still "personalized".Major religious organizations, such as NahdhatulUlama, Muhammadiyah, and others with varying degrees, still show strong or even strong personalization phenomena. Organizations in the field of youth, in the social field, and even in the field of education, many are still 'personalized', though varying degrees. In fact, it was so 'personalized' the organization in question, many of which were soon disbanded shortly after the leader died.

The phenomenon of "personalization" is also seen when an organization has difficulty in making a succession or a change of leadership. Monica and Jean Charlot called it, "Until a party has its successor, remain precarious "(Monica and Jean Charlot, 1985).

As long as an organization has not been able to cope with the crisis in its leadership turnover, and has not succeeded in laying down the basis of the regulation that can be recognized and trusted by its members, so long as the institutionalization of the organization is still problematic and can not be said to be strong. Moreover, if the change relates to a leader who is a founder who contributes to the organization concerned, it is often difficult to make an orderly and peaceful change. However, the degree of institutionalization of the organization concerned depends on how the issue of substitution can be made "impersonal" and "depersoanlized".

If we use this "personalization" parameter to assess the social organization and political parties in our homeland today, certainly a lot of organizations with different degrees can be said not all have been "depersonalized" institutionalized. Consider how parties like the
Golkar Party (GOLKAR), the National Mandate Party (PAN), the Indonesian Democratic Party of Struggle (PDIP), the National Awakening Party (PKB), the United Development Party (PPP), the Crescent Star Party (PBB) etc. Some are accompanied by divisions, some of which have not yet succeeded in organizing Congress forums, National Congresses or Muktamar.

In addition to the above two parameters, organizational degree can also be seen in terms of "organizational differentiation". A very important issue is the ability of the community organization or political party concerned to successfully organize itself as an instrument to mobilize its constituent support. Every democratic system with many political parties, a variety of political aspirations and interests competing in society requires proper channeling through the institutionalization of political parties.The more support that can be mobilized by and channeled its aspirations through a political party, the greater the potential of the political party to be called has been properly institutionalized.

To ensure its ability to mobilize and channel the constituent's aspirations, the organizational structures of the respective political parties must be structured in such a way that the range of interests in society can be accommodated and accommodated as widely as possible. Therefore, the internal structure of political parties is important to be properly structured. One side, should be in accordance with the need for mobilization of support and channeling constituent aspirations. On the other hand, the organizational structure of political parties must also be tailored to the format of governmental organizations idealized according to the vision of political parties requested to the constituents to provide their support. The more suitable the internal structure of the party organization with the need, the higher the degree of institutionalization of the organization concerned.

The four functions are equally related to one another. As a means of political communication, the party plays a very important role in the articulation of interests (interest articulation) or "political interests" that are sometimes or occasionally hidden in society. 
These interests are best absorbed by political parties into the ideas, visions and policies of the political parties concerned. After that, the ideas and policies or policy aspirations are advocated so that they can be expected to influence or even become official state policy material.

Associated with political communication, political parties also play an important role in socialization politics (political socialization). Idea, vision and strategic policy which become the choice of political party is conveyed to constituents to get 'feedback' in the form of support from the public. Related to this political socialization, the party also plays a very important role in the framework of political education.The party that becomes the intermediate structure or 'intermediate structure' should play a role in grounding the ideals of the state to foster the collective consciousness of citizens. For example, in the context of the need to socialize constitutional state awareness, parties can play an important role.

The importance of the role of political parties, should not mean that only political parties have exclusive responsibility to socialize the constitution. All circles and even political leaders who sit in public positions, especially executive government leaders have the same responsibility for it. An important aspect that is emphasized is that the role of political parties in the framework of political education and political socialization is very large.

The function of the three political parties is a means of political recruitment. The party was formed indeed intended to be a legitimate vehicle in the selection of cadres of state leaders at certain levels and positions. The cadres are directly elected by the people, some are elected by indirect means, such as by the House of Representatives, or through other indirect means. It is surely not all positions that can be filled by the role of political parties as a means of political recruitment. Professional positions in areas of personnel-employment, and others that are not political (poticial appointment), should not involve the role of political parties. The Party may only be involved in filling political positions and therefore require the appointment of its officials through political appointment.

In order to avoid confusion, it is necessary to correctly understand the difference between the political positions and the technicaladministrative and professional positions. For ministries, there is only one position that is political, namely the minister. While the assistant ministers in the environment he leads are civil servants who are subject to the laws and regulations applicable in the field of personnel. Different positions between state positions and civil service positions, ie those who occupy state positions referred to as state officials. It should, so simple, who occupy the position of civil servants called state officials. Public positions or civil service positions, especially civil servants, are known for two types of positions, namely structural positions and functional positions.

The respective positions have been determined very clearly in the hierarchy of career paths. For example, the level of structural positions is composed of echelons $5,4,3,2$, to echelon 1. For functional positions, the level of position is determined by the nature of work in each work unit. For example, for the lecturer at the highest college is a professor. The grid underneath is the head, lector, and assistant, assistant. For other fields, both the level and the nomenclature used vary depending on the field of work.

To fill the position or recruitment of state / state officials, either directly or indirectly, political parties can play a role. Related to this matter, the function of political party in the framework of political recruitment (political recruitment) is considered important. As for filling the position of the country as mentioned above, the party should be banned to engage and involve themselves.

The fourth function is conflict management and conflict management. As mentioned above, the values (values) and interests (interests) that grow in people's lives are very diverse, complex, and tend to compete with each other and collide with each other. If there are many political parties, these diverse interests can be channeled through the polarization of political parties that offer 
different ideologies, programs, and altrernative policies. Political parties play a role in regulating or managing conflict (conflict management), then carried out as a means of aggregation of interests that channel the different interests through the political channels of party institutions. Therefore, in the category of Meny and Knapp, the function of conflict managers can be linked to the function of integration of political parties. The Party aggregates and integrates these diverse interests by channeling them best to influence the political policies of the state.

Referring to Paige Johnson Tan's research, argues that political parties in Indonesia are significantly an important part of a consolidated democracy system, yet at the same time political parties are still weak institutionally. The party rests more on the charism of the leader, not on the modern organizational structuring system. This also implies the frequent occurrence of disunity in political parties resulting in the emergence of political frustrations of the cadre as well as the society and the impediments of the democratic consolidation process itself (Johnson Tan, 2012).

With regard to political parties and party systems, Andreas Uffen concluded that political parties in Southeast Asian countries, including Indonesia, are very weak in party politics, this is due to party party behavior and activities carried out by political parties (Ufen, 2008).

The organization of political parties sometimes acts aloud for and on behalf of the interests of the people, but in reality on the ground it actually fights for the benefit of its own board. As Michels puts it as an iron law prevailing in the organization that (Michels, 1962),

"The organization which gave birth to the domination of the elected to the electorate, between the mandate and the mandate and between the recipient of power and the giver. Anyone who talks about the organization, then actually he talks about the oligarchy".

To overcome the various potentials of political parties as stated above, then required a system that must be implemented consistently.First, the internal mechanisms that ensure democratization through the participation of political party members themselves in the decision-making process. Arrangement on this matter is very important formulated in writing in the constitution of the party and the household budget of the relevant political parties in the framework of "rule of law".

In addition to the articles of association and the household budget, according to the demands of development, it is necessary to introduce a system of positive ethical codes which are outlined as "Code of Ethics" which is guaranteed upright through an effective council of honor. On that basis, in the internal dynamics of party organization, there are three documents at once, namely "Code of Law" contained in the constitution of the political party, Code of Organic (code of organizational good conduct) contained in the household budget, and "Code of Ethics" in a separate document. Therefore, legal norms, moral norms, and ethical norms are expected to function effectively to build the internal culture of every political party. The rules set forth on paper are also clearly enforced in practice, so that the principle of 'rule of law' and 'rule of ethics' can be truly realized, from internal parties of political parties as sources of state leadership cadres.

These three normative codes describe the various working procedures of the board and their relationships with members, arrangements on internal institutions, institutional relations mechanisms, and elegant conflict resolution mechanisms that can be shared. So any disagreement can be properly channeled and conflicts can be overcome so as not to lead to undemocratic and usually uncivilized conflicts.

Second, the mechanism of party openness through outsiders may participate in determining the policies to be pursued through and by political parties. Political parties should be made and become a means of struggle of the people to participate in determining the workings of the state system according to their aspirations. The board should serve as a servant of aspirations and interests to his constituents. For that, it needs a paradigm shift in how to understand party and party activities. Being an administrator is not everything, the board should be a representative of the people. However, if the status as a determinant of whether or not a person becomes a representative of the people, 
then everyone will certainly compete to be a board and even top leaders of political parties.

As a result, becoming a board is considered a necessity, and one day it can be a representative of the people. Both are capped at once, and for the rest of the political party will only serve as a vehicle for the individual members of the board to continue to maintain a position as a representative of the people or to achieve other public positions. The management of political parties in the future should be directed to be a professional manager who is separated and separated from the candidates for the people's representatives. It may be helpful to think that the management of political parties is divided into 3 (three) components, namely (i) cadre components of the people's representatives, (ii) components of cadres of executive officers, and (iii) professional management components. All three are arranged in separate structures, and there can be no multiple positions and path choices. Recruitment and promotion patterns are required to follow the path specified in one of the three paths.

If a person is interested in becoming a member of the People's Legislative Assembly or the Regional People's Legislative Assembly, he shall be given the opportunity from the outset to become a member of the Party's Representative Council or which may be called by another name, provided by his own structure in the management of a political party. While the cadres who are interested in sitting in the executive branch does not sit in the people's representative institutions, should be placed in cabinet council or called by another name. In addition to the two structures it is a regular stewardship structure held by professionals paid by the party and is not intended to be recruited as a representative of the people or to be promoted to positions in government.

The three groups of management should not be mixed or too easy to move positions and paths. Even if there are people who want to move paths for rational reasons, then it can be possible to meet certain conditions, so it is not exactly 'stimulus' for the 'opportunists' that will undermine the rationality of the democratic culture and the rule of law in the party. To encourage the mechanism of stewardship and management of the party to be better, the regulation needs to be set forth in the laws and regulations of other legislation. It is not enough to be stipulated only in the articles of association and by-laws of the party concerned. The first and second mechanisms mentioned above relate to the internal aspects of the organization of political parties.

Third, the implementation of a good state with the increasing quality of public services (public services), as well as openness and accountability of power organizations in the implementation of state activities. If there is good public service with openness and accountability of government and other state organizers, the political climate will naturally grow healthy and will also become a fertile ground for political parties to develop in a healthy manner as well.

Fourth, the development of free press is increasingly professional and educational. Press media is a mass communication channel that reaches a very broad target. Its role in democracy is crucial. Therefore, the press is considered to be "the fourth estate of democracy", or to complete the term "triaspolitica" from Montesquieu, also called "quadrupolitica".

Fifth, the strong freedom of thought, freedom of expression, and freedom of peaceful assembly and association. In essence, the freedom in the life of the human race is the origin of freedom of thought. Starting from freedom of thought it further develops the principles of "freedom of belief", "freedom of expression", "freedom of assembly", "freedom of association", "feedom of the press", and so on and so on. Therefore, the climate or conditions that are necessary for the dynamics of growth and development of political parties in a country, is a climate of freedom of thought. That is, a good political party requires social land to grow, namely the freedom of thought among fellow citizens who will channel their political aspirations through one of the main channels, namely political parties.

Every 'representative democracy' system, it is commonly understood that sovereign people's participation is mainly channeled through popular vote to establish representative institutions. This representative mechanism is considered by itself to be effective for the purpose of ensuring the representation of the aspirations or the interests of the people. 
Therefore, in the representative system, the position and role of political parties are considered very dominant (Oliver, Prosser, \& Rawlings, 2011).

\section{DISCUSSION}

Political parties are an integral part of modern democratic systems. The challenge is how to organize political parties and make them function democratically. Compared to interest groups and civil society, political parties play a special role that can not be replaced by other organizations. This important role puts political parties in the central position (political centrality). This central position has two dimensions:

1. After successfully aggregating the various interests and values that exist within the

\section{Political Party Diagram}

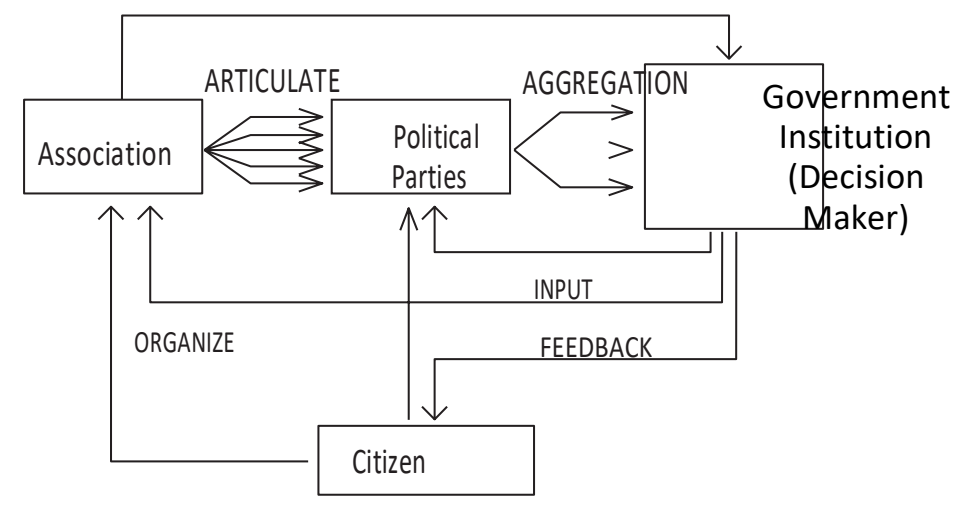

community, political parties then transform it into an agenda that can be used as an electoral platform. It is expected that the platform is able to attract a lot of votes from the people so that political parties will get many seats in parliament. Furthermore, political parties must be able to influence the political process in the legislation and implementation of the public policy program.

2. Political parties are the only parties who can translate the interests and values of the community into binding legislation and public policy. This can be done after they have gained a strong position in the regional and national parliaments.
Source: Thomas Meyer, 2012

Among the many functions of democratization by political parties, there are five very importants:

1. To aggregate interests and values and society

2. Explore, create, and introduce to the public the electoral platform of their political parties.

3. Arrange the process of political will (political will) by offering more structured policy alternatives.

4. Recruit, educate, and supervise competent staff for public office and to occupy parliamentary seats.

5. Socialize, educate, and offer members whose channels are effective for their political participation throughout the election period.

As with the strategic role of the political party mentioned above, we gain an information on the existence of a political party as a political instrument within the framework of democracy and million as a way to gain power. The problem then arises when the individuals within the political party are oriented only on how to gain that power, so that power becomes the final estuary of political contestation pursued by political parties. So the substantive goal of political activity that emphasizes the functional aspect of politics becomes neglected, namely to maintain or regulate the various kinds of public affairs. 
The activity of political parties only stops at the level of how to gain power, when it should not be so, but must be complemented by how the power which has been obtained is used for the greatest prosperity of the people. On the other hand there is an alienation of political parties to the community, resulting in the distance and the gap between political parties and the community. This great distance makes people start thinking that they can live without a political party. The saddest thing is the deep disappointment in society because they feel they have never been noticed and taken care of by political parties. This will clearly reduce the apolitical population rate, and reflected in the low political participation of the community in every election.

"People's trust in the political elite is almost at its nadir. This is because leaders and political parties no longer take sides with the people. This resulted in the people becoming a priori. Public participation is very low because political parties are judged to no longer reflect the interests of society as a whole "(Tony Situmorang, Political Observer of North Sumatra)".

In addition to the factors that only emphasize the orientation of power and the occurrence of alienation of political parties to the society, the problem faced by political parties is "corruption". Since 1999, the "tradition of corruption" ahead of the elections is a matter of course. In 1999, the BLBI corruption case rose to the forefront, followed by the 2004 election with bribery case of BI Governor Election Miranda Gultom to members of the House of Representatives for his win. In 2009, the Century Bank case shook the public with all its plays. In the 2014 election, corruption cases involving the Treasurer of the Democratic Party Nazaruddin flowing into political funding and allegedly for the preparation of elections 2014. Budget Agency of the House is also attached to corruption cases for the interests of political parties. Disbursement of Regional Infrastructure Development Acceleration Fund (DPID) is also allegedly full of corruption that ended in funding of political parties, the case of Wismaof Athletes, and also Hambalang. And there are many other corruption cases that are allegedly related to political parties.

\section{A.Political Parties in North Sumatera}

Political parties that have seats in the Provincial House of Representatives of North Sumatra Province there are as many as eleven political parties are converted into Nine Factions in the Regional House of Representatives Moss. The party that merges into one faction is the United Development Party (PPP), the Justice and Unity Party of Indonesia (PKPI) and the National Awakening Party (PKB). The number of seats in the House of Representatives of the Province of North Sumatra as many as 100 seats and spread in 11 political parties.

\section{Table 1.}

Fractions and Chairs of the House of Representatives of the Province of North Sumatra Province

Period 2014-2019

\begin{tabular}{|c|c|c|c|}
\hline $\begin{array}{l}\mathbf{N} \\
\mathbf{O}\end{array}$ & NAMA FRAKSI & KETUA & $\begin{array}{c}\text { JML. } \\
\text { KUR } \\
\text { SI }\end{array}$ \\
\hline 1 & PartaiGolkar & $\begin{array}{l}\text { IndraAlamsyah, } \\
\text { S.H. }\end{array}$ & 17 \\
\hline 2 & PDI Perjuangan & $\begin{array}{l}\text { Budiman P } \\
\text { Nadapdap, S.E. }\end{array}$ & 16 \\
\hline 3 & PartaiDemokrat & H. SalehBangun & 14 \\
\hline 4 & PartaiGerindra & $\begin{array}{l}\text { Ir. } \\
\text { YantoniPurba, } \\
\text { M.M. }\end{array}$ & 13 \\
\hline 5 & PartaiHanura & $\begin{array}{l}\text { AduhotSimamor } \\
\text { a }\end{array}$ & 10 \\
\hline 6 & $\begin{array}{l}\text { PartaiKeadilan } \\
\text { Sejahtera }\end{array}$ & Zulfikar & 9 \\
\hline 7 & $\begin{array}{l}\text { PartaiAmanatNasi } \\
\text { onal }\end{array}$ & $\begin{array}{l}\text { H. SyahAfandin, } \\
\text { S.H. }\end{array}$ & 6 \\
\hline 8 & PartaiNasDem & $\begin{array}{l}\text { Drs. Anhar A. } \\
\text { Monel, M.A.P. }\end{array}$ & 5 \\
\hline 9 & $\begin{array}{l}\text { PersatuanKeadilan } \\
\text { Bangsa }\end{array}$ & $\begin{array}{l}\text { RobiAgusmanHa } \\
\text { rahap, S.H. }\end{array}$ & 10 \\
\hline \multicolumn{3}{|c|}{ Jumlah } & 100 \\
\hline
\end{tabular}

Source: Secretariat of House of Representatives Council of North Sumatera Province

\section{B.Recruitment of PoliticalParties}

In the context of political recruitment for the legislature, there are some issues in political parties that have the potential to disrupt the development of democracy, especially at the local level of North Sumatra. First, the proportional 
electoral system has perpetuated the dominance of the oligarchy in the recruitment process. The party elite in the area is very powerful to the recruitment process, which determines who will occupy the "hat number" and who miserably occupies the "shoe number". However, the elite oligarchy pattern is not democratic, but tends to maintain the very closed practices of KKN. The pattern does not produce a representative and mandatory parliament, but rather a partisan parliament that is more loyal to the political party. Although the electoral system is no longer based on the serial number, but on the majority vote and / or who gets the Voter Distribution (BPP) score, the position of the sequential number determines the society's choice as well as the count when no one gets the BPP number.

"cadres who get the smallest serial number is usually will be filled by the party elites. I think in all the parties are doing the same thing and it is very common and natural to happen ". (SamsirPohan, Deputy Secretary of DPD Golkar of North Sumatra)"

Secondly, in the recruitment process there is no good linkage between political parties and civil society. Civil society is viewed only numerically as a number, not as a constituent that must be respected and championed. Community organizations are only placed as underbow, a political machine that mobilizes the masses, not as the basis of the party's political struggle. On the contrary, the activists of civil society organizations do not view political parties as part of the social movement to influence policy and control the state, but only as "political vehicles" to gain power and power. As a result, MPs are oriented only on power and wealth. Not a few DPRD members ignore extraparationary forums or participation, because they claim that the DPRD is the most legitimate representative institution and that participation is not regulated in local laws or regulations.

"until now we still can not trust the political party as a vehicle to fight for ideas and ideas of social movements that we build. The Party is still concerned with the power and sustainability of the political regime they build rather than the interests of society. This is of course still very much against our grassroots movement "(M Akbar Pribadi, Activist Labor)"

Third, in the process of recruitment of political parties often apply the "taking randomly" approach to candidates who are seen as "political machines". This approach tends to ignore the aspect of legitimacy, commitment, capacity, and mission of struggle. The former soldiers and officials are taken not because they have vision-missions, but because they have remnants of power networks. Employers are recruited for having a lot of money that can be used effectively for mobilization funds to money politics. Celebrities are taken because they have many fans. The scholars were also recruited for having traditional followers. Political parties easily take on social, intellectual, or academic figures on campus who pursue power and want to make the party a way for vertical mobility.

"Another problem in the recruitment of political parties in North Sumatra, both for the legislative and the executive is the lack of regeneration in the political party. This resulted in the party often doing "import" of cadres who ujukujuk could become the party's core executives without clear regeneration process. The purpose is only related to electoral values, money and influence ". (AkhyarAnshori, Academician).

In the limited focused discussions conducted, the fact that almost all political parties are performing character recruitment programs. The recruitment of the figures is intended for the party not to lose voters. Political parties in North Sumatra partly recruit public figures openly and there are some political parties that do so in private.

"to be honest, we political parties do not want to lose voters. When our cadres are not able to be votegetter, then we will look for a character who can be a votegetter and also has adequate financial strength. I think almost all parties do so, so do not be surprised if there are figures who often change the party at the time of the election arrived, because it is considered to have the ability to gain votes, so the political parties accept only politicians who often change the party "(Muslim Simbolon, House of Representatives Council Member of North PAN Faction).

Recruitment of the figures is done by open and closed model, the Hanura Party of 
North Sumatra, for example, make an announcement for the recruitment of figures with open, while PDIP recruit the characters with closed.

We do not argue that the recruitment of figures is a requirement of political parties to maintain the existence of the party. But in our PDIP, recruitment of our characters do with closed, meaning we do an internal evaluation before holding certain figures to enter in the PDIP, both as candidates for legislative and executive. (JumiranAbdi, Vice Chairman of DPD Indonesian Democratic Party of Struggle North Sumatera).

The process of political party recruitment in North Sumatra is indeed impressed to be done only as part of the process of performing the functions of the party alone. The size used is more focused on the person's personality and also the financial ability.

With very high political costs on every political event, both legislative and executive, it is no wonder we consider the cadres and figures who enter the party are those who have adequate financial strength2. (Roy Simanjuntak, Vice Chairman of DPD Democrats of North Sumatra).

Fourth, the electoral process and the recruitment process work in the context of a "less-educated and critical" floating mass. So far people have not received political education, especially from political parties, resulting in millions of traditional voters who are particularly vulnerable to mobilization practices. Political parties do not play an adequate role in political education to the public. Until now the majority of Indonesian people are silent majority, calm, apathetic (ignorant) and not critical in facing the political process. As a result, participative political culture (civic culture) has not been established. Conditions like this certainly do not allow for an open and participatory recruitment process.

"public apathy can not be separated from the role of political education conducted by political parties. I acknowledge that currently the political party is still not maximally in doing political works that lead to the political education of the community. Nevertheless, we at GerindraSumut have a youth political education program that we scheduled to do through party structures in the Province as well as in the Regency / City "(SugiatSantoso, Vice Chairman of DPD GerindraNorth Sumatera).

Recruitment of cadres conducted by political parties in North Sumatra is currently also done by taking cadres coming from the wing of the party organization, both youth, women and other party wings. This is done with consideration of the efficiency of party work in recruiting cadres, as well as associated with the lack of party financing issued when recruiting cadres through the existing party wing.

We undertake recruitment and subsequent regeneration of the Hanura party by appealing to young people we consider to be potential generations who can be politically and ideologically educated in the party. We do simple activities with young people through the party wing in the field of youth, then we lead the young people to go into politics through the regimentation in Hanura party "(FajriSiregar, Deputy Secretary of Hanura Party of North Sumatra).

In general, the political recruitment system in almost all political parties in North Sumatra, both for legislative and executive, has not gone well. Political parties do not yet have clear and rigid recruitment manuals governing how recruitment takes place. In some political parties, such as Golkar, PDIP which has a recruitment and regeneration module, the implementation stage is not consistently executed and strong commitment. This is of course very detrimental to the development of democracy at the local level, even at the national level. The model of recruitment of political parties in North Sumatra can be seen in the following table

\section{C.PoliticalParty Finances}

When political parties become election machines, political parties need large resources in order for them to function optimally in the ballot of voters. Whereas the waning of ideology has weakened the ties of political parties with its members which then had an impact on the fragility of the organization network. This of course has an impact on the decline of the 
political party's organizational capability in mobilizing supporters. As a result, political parties must find other ways to maintain the existence of political parties in society, and the ability to win votes in elections remains high in the elections.

Regardless of the method used, the effort to maintain the existence of political parties in the community and the effort to win votes as much as possible in the election, requires no small amount of funds. In addition to the lack of volunteer factors in supporting the activities of political parties-something that once was not a problem when political parties had strong ideological ties to their members-so the downward party organization network fell; factor development of communication technology has also led to increased campaign costs. Because the campaign is not enough to just hold a meeting and put a flag, but also must through mass media that costly.

Political parties are organizational channels used to gain power at both the legislative and executive levels and that is the constitutional mandate. The previous facts about the linkage between political corruption and party funding are often found.

The admission of some corruption inmates that they are corrupt because having to deposit money to a political party is another clue. So this is actually about the system. That is, the political system and party in Indonesia is indeed encouraging legislators and executive officers to perform corrupt acts. It has been described above that in the process of recruitment of political parties, the transactional process is a normal thing to happen. Indonesia's political system does create high costs. These high costs must be borne by political parties, legislative members, and executive officers.

"to become a candidate for regional head in North Sumatra at this time, it is common that the candidate must have hundreds of billions of money. In addition to the political costs of enormous winners, it is generally understood that in order to obtain the blessing of political parties to be promoted to pilkada, the pluralism is transactional. Although the candidate is the party's chairman, transactional still happens even if it is not as big as if an outsider wants to "woo" the party "(PangeranAhmadi, Political Observer of North Sumatra).

The very high political costs, besides having to be carried by the cadres and candidates carried, the political party must also be able to finance all activities before and after the election contestation implemented. Up to now for operational purposes only, political parties do not have a financial system capable of covering up. In almost all parties, the party fee does not work effectively for all members of the board.

In short, to maintain the existence of political parties in the community and to win votes in the election, political parties need substantial funds. This is the main problem facing political parties, at a time when political parties are no longer receiving financial support from their members. Studies show, since the 1960s, political parties everywhere experienced a decline in the number of members. The low number of members then has implications for the low financial ability of political parties, since political parties' finances are sourced from membership fees. Two decades later the political party began to rely on other sources of funding to finance its activities, and membership fees were increasingly meaningless.

Initially, political parties attracted contributions from sufficient income members who still had loyalty to political parties. Along with the increasingly expensive operational costs of political parties and campaign activities ahead of and during the election, political parties began to seek donations from outside the party. The targets are individuals or companies with limited numbers. But the longer the political parties increasingly have a dependence on individual contributors and companies. Today, almost all political parties in many countries funding sources to finance the activities of political parties are dominated by contributions from individuals and corporations as well as from the cadres they have distributed in both the legislative and the executive.

In such situations political parties face an existential ma-one, because the influence of the donor can change the nature of the political party, ie fight for the interests of members, voters or the 
people. The inclusion of large funds to political parties from donors is certainly not a casual donation, which is without reciprocal demand. Donors expect the benefits to be gained from political parties through policy-making or the use of other powers belonging to political cadres occupied both in the legislature and in the executive. In other words, the influx of donors' money can make political parties forget the interests of members, voters or society as a whole, and turn to champion the interests of donors.

"do not let the daily board pay party dues, even the party must foster and "menyantuni" the administrators who do not get political positions to run the organization. The way out is from our cadres who sit in the legislative as well as in the executive "(SugiatSantoso, Vice Chairman of GerindraSumut).

The financial problems of these political parties have become prominent in political parties, especially in North Sumatra. The cadres and party officials who have been sitting in the legislative or executive after political contestation will usually seek to raise money to repay debts from past elections. In addition, they also have to raise money for the upcoming election preparation. This causes corruption to remain an issue that has not been resolved either at the local level or at the national level.

\section{D.The Regeneration of Political Parties}

The form of cadre is influenced by party system and election system developed. However, whatever the system, in cadre, there are two important issues. First, how the efforts undertaken by the organization to improve skills both skills and knowledge. Secondly, it is the ability to provide the cadre or the organization's human resources, and especially to young people. Kaderisasi in the political party environment aims to give birth to cadres of nation-spirit leaders and party cadres generated must also be able to play its role as a creator capable of placing the existence of party in society. The system of the regeneration of political parties in Indonesia has different characteristics between one party and another, adjusted to the AD / ART set by the party. In its implementation, many parties are unable to implement strict and terideological cadre. This is evidenced by the number of party cadres who "jump" from one party to another if the general election arrives.

Political parties in North Sumatra are generally still constrained by the absence of rigid cadre system documentation and consistently implemented by political parties. Even if the document of the cadre method exists, the problem with implementation is related to the minimal party infrastructure at the provincial level, as well as the constraints on the issue of financing.

"We have mechanisms for conducting internal party cadres, but at the level of North Sumatra it is rather difficult to implement. This is related to human resources that are able to achieve it is limited, also related to the financing that is not there and must be sought by the party at the local level. Even if there are cadres conducted through the DPP, it is usually ineffective and less likely to create militant and terideological cadres "(SugiatSantoso, Vice Chairman of GerindraSumut).

The field findings of this study also indicate that the regeneration program conducted by political parties through party schools and party training does not produce maximum output. It is impressed that such activities are carried out only to fulfill the formal work program of the party.

"We must admit that all the parties'cadreisation activities, whether party schools, technical guidance and so on, are only limited to formal activities and routines. Mostly no follow-up and outcomes are produced significantly for the progress of the political party ". (Wake Tampubolon, Deputy Chairman of North Sumatra Democrat).

\section{CONCLUSION}

Based on the results of the research described in previous chapters, the problems that occur in political parties, especially in North Sumatra are caused by the weakness of the regeneration system, political recruitment as well as internal party finance. The majority of political parties have no structured and systematic, as well as financial management that is largely not derived from party contributions, but the nonbinding contribution of cadres who have served 
in certain political positions. In addition, the electoral system in both the legislative and the elections has exacerbated the birth of the regeneration system, the recruitment and financial of political parties. Although in the case of the finances of political parties is currently still rolling discourse gave birth to a rule that allows political parties get substantial funding by the state through the State Budget Revenue.

The pattern of regeneration, recruitment and financial system within the political party body must be improved by modeling some models of management of political parties in developed countries. Furthermore, it should be avoided the birth of karbitan cadres who join the political party only because of the popularity factor and the funds they have so with the capital it is believed they will win and can support the party. Therefore, political parties must reorganize themselves, complemented by a complete overhaul of the political system and party system in Indonesia, as well as a powerful set of rules to monitor and open the funding of political parties in order to avoid infidelity between politicians and businessmen as a result of the political contracts they woke up.

\section{BIBLIOGRAPHY}

Bader, V. (2014). Crisis of political parties and representative democracies: rethinking parties in associational, experimentalist governance. Critical Review of International Social and Political Philosophy, 17(3), 350376.

Bale, T. (2015). If opposition is an art, is Ed Miliband an artist? A framework for evaluating leaders of the opposition. Parliamentary Affairs, 68(1), 58-76.

Choi, N. (2011). Local politics in Indonesia : pathways to power. Routledge contemporary Southeast Asia series.

Cross, W., \& Gauja, A. (2014). Evolving membership strategies in Australian political parties. Australian Journal of Political Science, 49(4), 611-625.

Dahl, R. A. (1971). Dahl- Polyarchy. In Polyarchy: Participation and Opposition (pp. 1-16).

Diamond, L. (1999). Defining and Developing Democracy. Developing Democracy: Towards Consolidation, 1-23.
DUVERGER, M. (1980). A NEW POLITICAL SYSTEM MODEL: SEMI???PRESIDENTIAL GOVERNMENT. European Journal of Political Research, 8(2), 165-187.

Fukuoka, Y. (2013). Democratization Indonesia's "democratic transition" revisited : a clientelist model of political transition. Democratization, 20(April 2015), 37-41.

Johnson Tan, P. (2012). Reining in the Reign of the Parties: Political Parties in Contemporary Indonesia. Asian Journal of Political Science, 20(2), 154-179.

Kalua, P. (2011). Forum for Development Studies The Extent of Political Party Institutionalization in Malawi : The Case of United Democratic Front ( UDF ) and Malawi Congress Party ( MCP) The Extent of Political Party Institutionalization in Malawi : The. Forum for Development Studies, 38(February 2015), 37-41.

Lofland, J., \& Lofland, L. H. (1995). Typological Systems: Analyzing social settings. Typological Systems: Analyzing social settings.

Mený, Y., \& Surel, Y. (2002). The Constitutive Ambiguity of Populism. In Democracies and the Populist Challenge (pp. 1-21).

Michels, R. (1962). Oligarchy. In The Sociology of Organizations: Basic Studies.

Oliver, D., Prosser, T., \& Rawlings, R. (2011). The Regulatory State: Constitutional Implications. The Regulatory State: Constitutional Implications.

Randall, V., \& Svåsand, L. (2002). Party Institutionalization in New Democracies. Party Politics, 8(1), 5-29.

Rousseau, J.-J. (1999). The Social Contract. Theology (Vol. III). Retrieved from http://www.amazon.com/Social-ContractJean-Jacques-Rousseau/dp/145380689X

Scarrow, S. E. (2009). Political Activism and Party Members. In The Oxford Handbook of Political Behavior.

Schattschneider, E. (1942). Party Government. American government in action series.

Ufen, A. (2008). Political party and party system institutionalization in Southeast Asia: lessons for democratic consolidation in Indonesia, the Philippines and Thailand. The 
Pacific Review, 21(3), 327-350.

Webb, P., Poletti, M., \& Bale, T. (2017). So who

really does the donkey work in "multi-speed membership parties"? Comparing the election campaign activity of party members and party supporters. Electoral Studies, 46 , 64-74.

Yin, R. K. (2009). Case Study Research: Design and Methods. Essential guide to qualitative methods in organizational research (Vol. 5). 